\title{
The Middle Miocene insectivores from Sámsonháza 3 (Hungary, Nógrád County): Biostratigraphical and palaeoenvironmental notes near to the Middle Miocene Cooling
}

\author{
JÉRÔMe PRIETO, LARS W. VAN den HOEK OSTENDE \& JÁNOS Hír
}

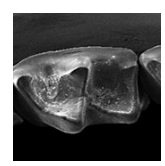

\begin{abstract}
Large and well preserved micro-mammal faunas are available from the Middle Miocene from Hungary, but very little attention was paid on insectivores, although this group provides good palaeoenvironmental and palaeogeographical indication. As a first step we review the material from Sámsonháza 3 (Hungary, Nógrád County), based on both published and new fossils. We report the dimylid Plesiodimylus sp., the soricid cf. Paenelimnoecus sp. and an indeterminate shrew. The erinaceids Parasorex sp. and Lantanotherium sp., and the talpid Desmanodon sp. are described for the first time from Hungarian deposits. The fauna indicates a relatively wet environment and is in agreement with the Middle Badenian correlation proposed on the basis of the rich molluscan fauna of the locality. - Key words: Mammalia, Erinaceomorpha, Soricomorpha, biostratigraphy, palaeoenvironment.
\end{abstract}

PRIETO, J., HoEk OSTENDE, L.W. VAN DEN \& HÍR, J. 2012. The Middle Miocene insectivores from Sámsonháza 3 (Hungary, Nógrád County): Biostratigraphical and palaeoenvironmental notes near to the Middle Miocene Cooling. Bulletin of Geosciences 87(2), 227-240 (3 figures). Czech Geological Survey, Prague. ISSN 1214-1119. Manuscript received July 4, 2011; accepted in revised form January 2, 2012; published online March 14, 2012; issued March 30, 2012.

Jérôme Prieto (corresponding author), Institute for Geoscience, and Senckenberg Center for Human Evolution and Palaeoecology (HEP), Sigwartstraße 10, 72076 Tübingen, Germany; Department für Geo- und Umweltwissenschaften, Paläontologie und Geobiologie, and Bayerische Staatssammlung für Paläontologie und Geologie, Richard-Wagner-Str. 10, 80333 München; j.prieto@lrz.uni-muenchen.de • Lars W. van den Hoek Ostende, Netherlands Centre for Biodiversity, Naturalis, P.O. Box 9517, NL-2300 RA Leiden, The Netherlands • János Hír, Nógrád Megyei Múzeumi Szervezet, Pásztói Múzeum, 3060, Pásztó, Múzeum tér 5, Hungary

During the last decade, intensive field work in the Miocene deposits from Hungary has lead in the discovery of large and well-preserved micromammal faunas (e.g., Hír 2010). As a result, much progress had been made in the understanding of the rodent biostratigraphy and faunal relationships in Eastern Europe. Paradoxically, few studies were undertaken on the Middle Miocene insectivore samples, most of the efforts being focused on younger records (e.g. Reumer 1984, Mészáros 2000a, b and references therein). This lack is unfortunate, as this group is traditionally considered a good palaeoenvironmental indicator (particularly for humidity), and recently also proved its importance for palaeogeographical purposes (Furió et al. 2011). As a matter of fact, the central position of Hungary makes its palaeogeographical importance evident. The more so for the Middle Miocene, when it provided the northern border of the Paratethys, and formed thus part of one of the major access routes to Western Europe. Furthermore, it provides a logical link between the well-defined records of the North Alpine Foreland Basis, and the far lesser known faunas from Eastern Europe.
Such a strategic position is of particular interest in terms of large changes. Following the Miocene Climatic Optimum, a dramatic and abrupt decrease in temperature (Middle Miocene Cooling) occurred at the Middle/Late Badenian transition at around 14-13.5 Ma, which had a clear impact in the composition of the vertebrate faunas (Böhme 2003). Thus, knowledge of the East European insectivore faunas will help us to track the faunal movements in that period.

As a first step in the elaboration of the Middle Miocene insectivore faunas from Hungary, we review the material from Sámsonháza 3, based on both published (Hír \& Mészáros 2002) and new fossils.

\section{The locality}

The Sámsonháza 3 fauna (abbreviated S3) has been sampled in the Oszkoruzsa valley of the Buda Hill, close to the small village of Sámsonháza (see details in Hír et al. 1998 
and Hír \& Mészáros 2002). The SW slope of the Buda Hill is the type section of the early Badenian Sámsonháza Formation (Haas 2001), which contains rich marine faunas (Hámor 1985). The bone bearing layer S3 occurs at the top of this formation. Beside a rich invertebrate assemblage referable to the Middle Badenian (Hír \& Mészáros 2002, p. 22), lower vertebrates (Venczel \& Csiki 2002, Venczel 2004, Venczel \& Știucă 2008, Venczel 2011), small mammals constitute a large part of the fauna of S3, the richest locality of the Oszkoruzsa valley. Based on the evolutionary level of the large-sized cricetid rodent Cricetodon, Hír \& Mészáros (2002) proposes that S3 is slightly younger than the geographically close locality Hasznos (Kordos 1986), traditionally correlated to the MN 6 (e.g. De Bruijn et al. 1993). Some authors consider the locality being younger (e.g. Bolliger 1999), but this is based on Kordos' (1986) original erroneous assignment of the Cricetodontini to the species Deperetomys hagni (occurrence: MN 7 and 8 in the North Alpine Foreland Basin, e.g. Engesser 1972).

Three other fossil layers ( $\mathrm{S} 0$ to $\mathrm{S} 2$ ) of minor importance have been excavated in the Oszkoruzsa valley, and presented by Gál et al. (2000), Hír \& Mészáros (2002) and Venczel (2008).

Other rich faunas are reported close to Sámsonháza in the Late Badenian deposits from Mátraszôloos (Mátra Mountains, Gál et al. 1999, 2000, Hír \& Kókay 2004).

\section{Methods}

Descriptive terminologies and measurement methods of the specimens follow: Soricidae: Reumer (1984), as revised by Ziegler (1989). Talpidae: Ziegler (2003a); Erinaceidae: Prieto et al. (2010). Concerning the Dimylidae, most of the authors used Müller's (1967, figs 1-6) method. He indicated on page 9 that the lingual border is the baseline for the measurements of the teeth, with the exception of the premolars that are rounded. However, his figure 5 shows that protocone and hypocone are not on line. Therefore, using the lingual outline, it is difficult to provide consistent measurements. Here we use the labial border as baseline, and consider the anterior and posterior widths. In order to avoid differences in measurement method, the original material from Hír \& Mészáros (2002) has been re-measured.

All measurements are given in $\mathrm{mm}$, and all specimens are presented in the left orientation in the figures (i.e. reversed for right elements). SEM photos were taken at the Biogeology and Applied Paleontology laboratory of the Eberhard Karls University in Tübingen.

Abbreviations. - L: length; BL: buccal length; W: width; AW: anterior width; PE: length to the posterior emargina- tion; L1, L2, W1, W2, see Prieto et al. 2010; ant: anterior; post.: posterior; S3: Sámsonháza 3; PM: Museum Pásztó; FO: first occurence.

\section{Systematic palaeontology}

Order Erinaceomorpha Gregory, 1910

Family Erinaceidae Fischer, 1814

Subfamily Galericinae Pomel, 1848

\section{Genus Parasorex von Meyer, 1865}

Type species. - Parasorex socialis von Meyer, 1865.

Diagnosis (emended). - Van den Hoek Ostende (2001a); because of taxonomical problems, especially at the genus level (Galerix, Parasorex and Schizogalerix), no complete or substantial differential diagnosis is provided in the literature; partial differences are reported in Van den Hoek Ostende (2001a).

Other species included in Parasorex. - P. depereti (Crochet, 1986), P. ibericus (Mein \& Martín-Suárez, 1993), $P$. pristinus (Ziegler, 2003).

We include $P$. kostakii (Doukas \& Van den Hoek Ostende, 2006, see below).

\section{Parasorex sp.}

Figure $1 \mathrm{~A}-\mathrm{F}$

1998 Galerix exilis (Blainville, 1838). - Hír et al., pp. 182, 183.

2002 Galerix exilis Blainville, 1839. - Hír \& Mészáros, pp. 10, 11, fig. 3, 1-3.

pars 2002 Talpidae gen. et sp. indet. - Hír \& Mészáros, p. 12.

Material. - 1 P? (PM 2004.393.7), 7 P4 (2004.352, 2004.358, 2004.357, 2004.356, 2004.355, 2004.393.10, 2004.393.18), 2 M1 (PM 2004.349, 2004.353), 6 M2 (PM 2004.393.1, 2004.393.5, 2004.393.6, 2004.354, 2004.359, 2004.360), 1 fragmentary M (PM 2004.391), 1 M3 (PM 2004.351), 1 c (PM 2004.363), 1 fragmentary mandible with p4-m2 (PM 2004.350), 1 p4 (PM 2004.393.4), 4 m1 (PM 2004.393.3, 2004.362, 2004.364, 2004.365), 2 m2 (PM 2004.393.2, 2004.393.8), 2 fragmentary m1,2? (2004.347-1, 2004.347-2).

Measurements. $-\mathrm{P} 4(\mathrm{~L} \times \mathrm{W} 1-\mathrm{W} 2): 2.35 \times 2.44-2.85 ; \mathrm{M} 1$ $(\mathrm{L} \times \mathrm{W} 1-\mathrm{W} 2): \sim 2.50 \times \sim 2.75-\sim 2.67 ; 2.76 \times \sim 3.14-\sim 3.46$; M2 (L $\times$ W1-W2): $2.34 \times 3.17-3.02 ; 2.17 \times 2.96-2.81 ;$ M3 $(\mathrm{L} 1-\mathrm{L} 2 \times \mathrm{W}): 1.55-1.52 \times 1.89 ; \mathrm{p} 4: 1.98 \times 1.28 ; \mathrm{m} 1(\mathrm{~L} \times$ W1-W2): $3.11 \times 1.80-1.97$. 
Description. - P4: the labial border of the premolar is not straight, and a notch is present posteriorly to the paracone; the parastyle is well developed; there are two lingual cusps: the protocone is higher than the hypocone; a narrow crest extends from the protocone to the base of the paracone; the hypocone is connected to the posterior cingulum; the lingual cusps are connected by a narrow crest which descends from the protocone in one tooth (Fig. 1A); the crest corresponds to an anterior arm of the hypocone in three $\mathrm{P} 4 \mathrm{~s}$, or is absent in one premolar; a small cingulum may be developed on the lingual border of the premolar, between the two cusps; three roots.

M1: the mesostyle is undivided; the posterior arm of the paracone is shlightly curved, and connects anterolabially to the metacone; the parastyle is well developed, with a very small posterior crest ending on the labial wall of the paracone; the parastyle is connected to the anterior cingulum; a very narrow labial cingulum is developed; the anterior arm of the metaconule is short, the posterior arm is long and reaches the posterolabial border of the M1; this posterior arm is not directly connected to the posterior cingulum (PM 2004.353); the protocone-metaconulus connection is absent in one tooth, present in the other M1; the protoconulus is a mere bulge in the anterior arm of the protocone; four roots, the two lingual roots being fused at their basis.

M2: the M2 differs from the M1 in the usual galericine characteristics; the labial border is concave, and a narrow cingulum is developed along the paracone; the parastyle is fused with the anterior cingulum, and in connection with the paracone; the anterior arm of the protoconule is better developed than in the $\mathrm{M} 1$; the protocone is connected to the base of the metaconule in two M2s, this connection is missing in two other teeth; on the figured M2 the mesostyle is superficially fissured, a characteristic which is not recognized on the other specimens; three roots.

M3: the single M3 is worn; the anterior cingulum and parastyle are well developed; the anterior arm of the protocone extends onto the protoconulus, which is fused with the anterior cingulum; three roots.

Mandible: the single find is very fragmentary, but the posterior rim of the mental foramen is distinguishable under the anterior root of the $\mathrm{p} 4$.

p4: All p4s are damaged, at least partially; the best preserved last premolar shows the presence of a paralophid; the protoconid and the high metaconid are close together, and connected by a crest descending from the protoconid; two roots.

$\mathrm{m} 1$ and $\mathrm{m} 2$ : the teeth show the standard morphology of the galericine lower molars; as particularities, it can be noticed, that the entoconid does not develop an entocristid, and the posterior cingulid reaches the base of the entoconid, but does not fuse with the hypolophid on the well preserved $\mathrm{m} 1$ of the mandible.
Discussion. - Taxonomical homogeneity of the sample: The occurrence of two sympatric galericines is not rare in the fossil record, and, in some cases, two morphologically close species can make the study difficult. For instance Kälin \& Engesser (2001) found two Schizogalerix species in Nebelbergweg, or two Schizogalerix are reported from Sofça (Engesser 1980). In our case, the sample seems to be homogeneous, with regards to both morphological and metrical arguments.

Remarks on the genera Parasorex, Schizogalerix and Galerix: At one time, all species referred to these three genera were placed in Galerix (see historical background in Doukas \& Van den Hoek Ostende 2006, pp.112-113). Although important efforts were made in order to understand the taxonomy and phylogeny of the group, the interpretation is still a matter of debate (e.g. Butler 1980, Engesser 1980, Van den Hoek Ostende 2001a, Ziegler 2005, Doukas \& Van den Hoek Ostende 2006, Prieto et al. 2011). As a result, the generic assignment of some species depends on the relative importance given to different morphological characteristics. Moreover, some early forms can share characteristics of different genera. It is out of the scope of this paper to revise once more this taxonomy, a revision which anyway needs intense morphological study supported by long-distance correlations.

With regards to the morphology, the main characteristics of the species from S3 are:

- the protocone-metaconule connection in some of the M1 and M2;

- the undivided and only slightly S-shaped mesostyle of the M1 and M2;

- the long posterior arm of the metaconule of the M1 and M2;

- the upper molars are not transversally elongated;

- the paralophid of the $\mathrm{p} 4$.

The $\mathrm{P} 3$ and the $\mathrm{p} 2 / \mathrm{p} 3$ ratio, both considered important in galericine taxonomy, are unfortunately not known.

These characteristics link, at least partially, the Hungarian species to the following Lower, Middle and earliest Late Miocene galericines (original taxonomy)

1) Schizogalerix pristina from Mühlbach am Manhartsberg (Austria, Early Middle Miocene, Ziegler 2003b, = Parasorex pristinus in Doukas \& Van den Hoek Ostende 2006): Based on the plate in Ziegler (2003b), the M1 from Mühlbach seems to be too large in comparison to the M2s. Therefore we checked the original material. We are satisfied that the relatively large M1 is an artefact in reproduction. However, we did come to some different interpretations than Ziegler. The $\mathrm{m} 2$ originally assigned to Galerix cf. aurelianensis seems better placed within Schizogalerix pristina, because of its narrow trigonid, up sloping posterior cingulum and size. The single M3 assigned to $G$. cf. aurelianensis is peculiar in having an enormous parastyle, which accounts for the far larger size than the other M3 of the site. A single somewhat aberrant M3 is, 
however, in our opinion too weak a ground to assume the presence of two galericines in Mühlbach.

The molars from the Austrian sample are somewhat smaller than S3, and they lack the protocone-metaconule connection, although a possible connection is indicated in one worn specimen. The hypocone of the M1 and M2 is weaker developed than in S3.

The M2 from Grund (Austria, Early Badenian), was similarly assigned to Schizogalerix pristina. However, the hypocone is far better developed than in the Mühlbach, the molar is relatively longer and is overall larger. It is basically not different from the Hungarian M2.

2) Galerix kostakii from Karydia (Greece, Early Miocene, Doukas \& Van den Hoek Ostende 2006): this species differs from Schizogalerix pristina in the longer molars, and the straight anterior arm of the metacone. Whereas the $\mathrm{S} 3$ species agrees well in size, the M2s have a concave labial border, differing from the Greek form (border almost straight). The $\mathrm{m} 1$ trigonid of the Hungarian species is less open than in Galerix kostakii.

3) "Schizogalerix" iliensis from Aktau (Kazakhstan, Early Miocene, Kordikova 2000): The measurement method of Kordikova differs clearly from ours and metrical comparisons are difficult for the upper molars; similarly the lower teeth of both localities do not allow confident analyze. Morphologically the mesostyle of the upper molars from Aktau is clearly S-shaped, the posterior arm of the metaconule can be short, and there is no protocone-metaconule connection.

4) Schizogalerix pasalarensis from Paşalar (Turkey, Middle Miocene, Engesser 1980): S. pasalarensis lacks the protocone-metaconule connection, the mesostyle of the M1 is clearly S-shaped, and the upper first two molars are diagonally elongated. In the $\mathrm{P} 4$, the protocone and hypocone are not connected. Similar differences are observed in the descendant of the species from Pașalar, S. aff. anatolica from Çandir (Turkey, Middle Miocene, De Bruijn et al. 2003).

5) Parasorex socialis from diverse localities (here all German, Middle Miocene, see Ziegler 2005, Prieto 2007, Prieto \& Rummel 2009a; Iberian samples attributed to this species are excluded because of taxonomical incertitude (Prieto et al. 2011, Furió et al. 2011): the species lacks a clear protocone-metaconule connection, although a tendency to develop this connection can be observed in some samples. In comparison to the S3 galericine, the M2s have a less concave labial border. In the German p4, the protoconid and metaconid are separated anteriorly by a deep valley, and the metaconid is not so high. In the $\mathrm{P} 4$, the protocone and hypocone are not connected.

6) Galerix symeonidisi from Aliveri (Greece, Early Miocene, Doukas 1986): the teeth from Greece are clearly smaller, but share morphological characteristics with S3 as, for instance, the connection protocone-hypocone in some $\mathrm{P} 4$, the junction protocone-metaconule in some M1/M2, the concave labial border of the M2. But, an important taxonomical characteristic, the $\mathrm{p} 4$ does not have a continuous paralophid, and the posterior arm of the metaconule is shorter in some specimens. Large samples of $G$. symeonidisi are also reported from Central and Western Europe, but the phylogeny of these forms (relationships G. symeonidisi/G. exilis; Ziegler \& Fahlbusch 1986, Van den Hoek Ostende \& Doukas 2003) is controversial. Thus we restrict the comparison to the type locality, Aliveri.

7) Galerix saratji from Kilçak, Harami and Kargi (Turkey, Early Miocene, Van den Hoek Ostende 1992, 2001b): the Anatolian species is clearly smaller than S3, has always the connection protocone-metaconule and lacks the paralophid on the $\mathrm{p} 4$. The two species share, beside the long posterior arm of the metaconule, the connected lingual conules on the P4.

8) Galerix rutlandae from Daud Khel (Pakistan, Early Miocene, Munthe \& West 1980): the species shares with the teeth from S3 the following characteristics: connection protocone-metaconule, p4 with paralophid. The single p4 of G. rutlandae is much more quadratic, with the paraconid being closer to the protoconid than in S3. Furthermore, in the M2 from Pakistan the anterior arm of the protocone connects to the paracone. The overall outlines of the second molars are also completely different.

Some samples left in open nomenclature are also important for our comparisons:

9) Galericinae gen. et sp. indet. from Gratkorn (Austria, late Middle Miocene, Prieto et al. 2010): the single M1 from Gratkorn (strongly corroded) does not differ basically from the corresponding corresponding molars from S3.

10) Schizogalerix nov. sp. from Nebelbergweg (Switzerland, around the Middle to Late Miocene transition, Kälin \& Engesser 2001): this large but poorly documented species differs from S3 mainly in the form of the mesostyl.

11) Schizogalerix sp. from Antonios (Greece, Early-Middle Miocene, Vasileiadou \& Koufos 2005): the upper molars lack the protocone-metaconule connection, but the material from this locality is limited. Some P4 have a small ridge connecting the two lingual cusps, as in S3. The Hungarian specimens are slightly larger.

12) Galerix sp. from Komoniti (Greece, MN5, Doukas \& Van den Hoek Ostende 2006): a single M1 was excavated in the locality. It differs from Galerix kostakii in its larger size, and does not fit with S3 at least in its robustness and the form of the mesostyl.

The species from S3 is morphogically close to a couple of species, which are, however, assigned to different genera. According to Van den Hoek Ostende (2001a) all 


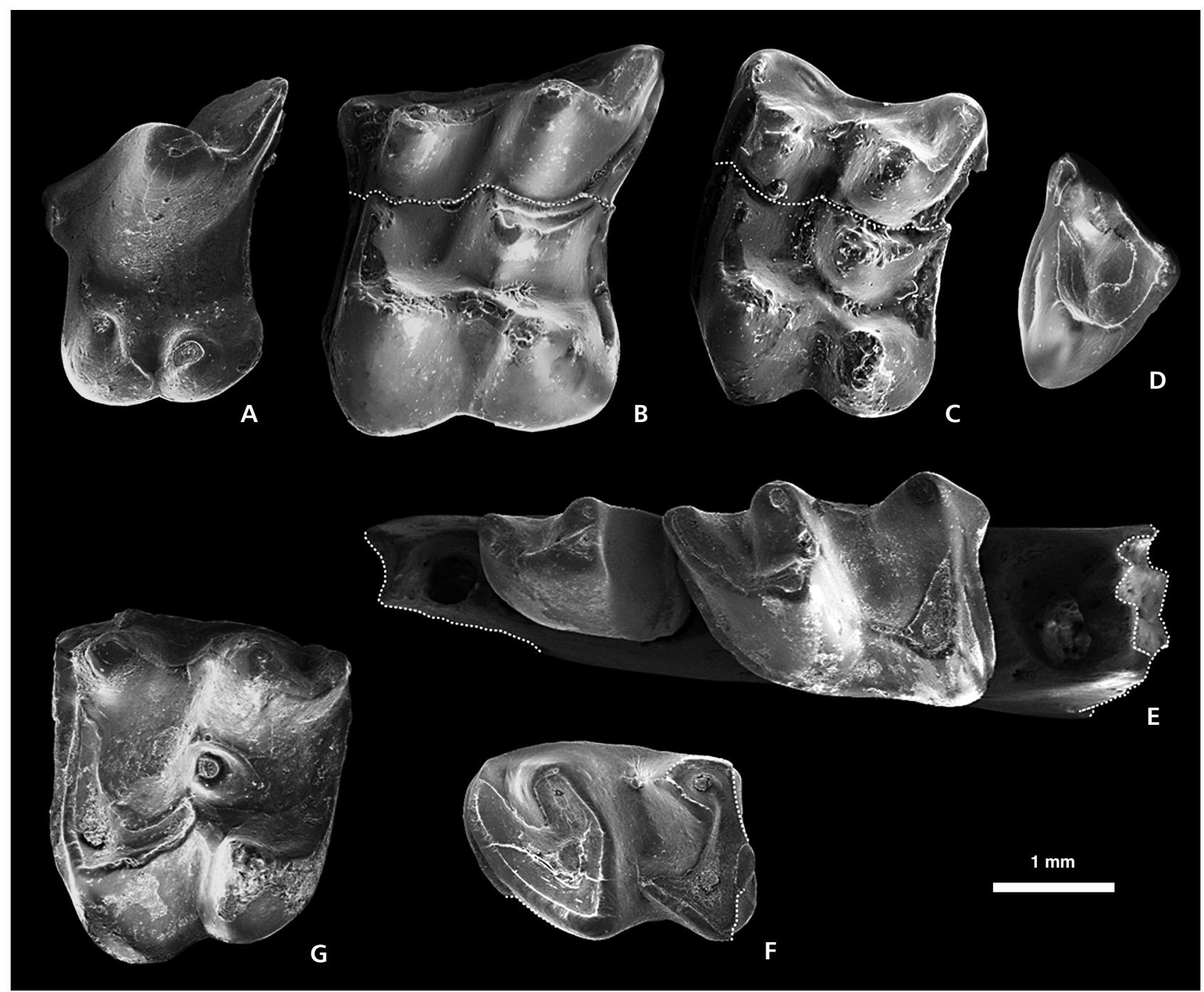

Figure 1. A-F - Parasorex sp. • A - left P4 (PM 2004.352); B - right M1 (reversed, PM 2004.353); C - left M2 (PM 2004.354); D - right M3 (reversed, PM 2004.351); E - right mandible with p4-m1 (PM 2004.350; the fragmentary $\mathrm{m} 2$ belonging to this specimen is not figured); F - right $\mathrm{m} 2$ (reversed, PM 2004.393.2). • G - Lantanotherium sansaniense (Lartet, 1851) vel Lantanotherium longirostre Thenius, 1949, right M2 (reversed, PM 2004.366).

Parasorex/Schizogalerix species do not show the connection protocone-metaconule, a characteristic particuliar to Galerix. On the other hand, the presence of a paralophid on the $\mathrm{p} 4$ excludes most of the Galerix species, with the exception of G. kotsakii and G. rutlandae.

Assigning the S3 sample to a genus, we either have to accept that a Galerix species could have a paralophid on the p4, or that part of the M2 in a Parasorex assemblage can have the protocone-metaconule connection. The paralophid of the p4 is in Parasorex and Schizogalerix strongly linked to the presence of a hypocone on the P3 in the European and Anatolian fossil record. Thus, this is a very basic character. On the other hand, the lack of a protoconemetaconule connection seems to be a secondary phenomenon, and could be the result of another characteristic of the molars in these genera, the wider M1 and M2 (Van den Hoek Ostende 2001, fig. 2). Therefore, we put more weight on the morphology of the p4, and classify the sample as Parasorex. As a primitive species, it is clear that the molars from S3 are not strongly widened, and hence the occasional presence of a protocone-metaconule connection understandable. Following this proposal, G. kostakii should be viewed as early Parasorex. The case of $G$. rutlandae is difficult because the species show a paralophid on the $\mathrm{p} 4$ (Parasorex-like), but also P3 without hypocone (Galerixlike). More material from the species is needed to solve the problem.

Doukas \& Van den Hoek Ostende (2006) propose the lineage Galerix symeonidisi-Parasorex kostakiiParasorex pristinus. As shown before, these forms share 
morphological characteristics with the Hungarian sample, but, with regards to the limited material in S3, any definitive phylogenetic conclusion is hazardous.

Gál et al. (1999) report Schizogalerix anatolica Engesser, 1980 in the Late Badenian fauna of Mátraszólós 1, probably based on the same specimens as Hír \& Kókay (2004, p. 94) assigned to Galerix exilis. As the specimens have not been figured, this cannot be ascertained. Thus a review of the insectivore samples from Mátraszólós is necessary and will be discussed in a separate paper.

\section{Genus Lantanotherium von Meyer, 1965}

Type species. - Lantanotherium sansaniense (Lartet, 1851).

Diagnosis (emended). - Engesser 2009.

Other species included. - L. robustum Viret, 1940, L. sanmigueli Villalta \& Crusafont, 1944, L. longirostre Thenius, 1949, L. piveteaui Crusafont, Villalta \& Truyols, 1955, L. sawini James, 1963, L. dehmi James, 1963, L. lactorensis Baudelot \& Crouzel, 1976, L. sabinae Mein \& Ginsburg, 2002.

\section{Lantanotherium sansaniense (Lartet, 1851) vel Lantanotherium longirostre Thenius, 1949 Figure 1G}

?1998 Erinaceidae gen. et sp. indet. - Hír et al., p. 183. 2002 Mioechinus sp. - Hír \& Mészáros, p. 11, fig. 4.

Type localities. - Lantanotherium sansaniense: Sansan (France); L. longirostre: Leoben (Austria).

Stratigraphic correlation. - Sansan (L. sansaniensis): Middle Miocene, MN 6 (reference locality, see details in Ginsburg \& Bulot 2000, Sen \& Ginsburg 2000).

Leoben (L. longirostre): Middle Miocene, Badenian, MN 5 in Ziegler (1999).

Material and measurements. - 2 M2 (PM 2004.366, 2004.393.17): $(\mathrm{L} \times \mathrm{W} 1-\mathrm{W} 2) 2.67 \times 3.02-2.73 ; 2.67 \times$ 2.93-2.70.

Description and discussion. - The overall morphology of the M2s basically does not differ from the published material from Sansan (Engesser 2009). The protoconule is single-branched and does not connect to the parastyle. Notably, the molars from S3 have a relatively narrow posterior side, as the protocone has a clearly more lingual position than the hypocone.
Lantanotherium piveteaui, L. lactorensis and L. sabinae are only known by their holotypes, which are fragmentary lower jaws, and thus cannot be compared directly with the two M2s from S3. The first two are of an Early Miocene age, and are not considered for that reason. L. sabinae was described as being larger than L. sansaniensis, whereas the S3 molars are smaller than those from the type locality, based on the measurements given by Engesser (2009). Thus, L. sabiniae can also be excluded. Lantanotherium sanmigueli is clearly smaller, whereas L. robustum surpasses the Hungarian species in size. Lantanotherium sansaniensis, and particularly the somewhat larger specimens of $L$. aff. sansaniense (e.g. Hambach 6C, Ziegler \& Mörs 2000) fit with S3. According to Thenius (1949, p. 47), L. longirostre is close to L. sansaniense, and differs in characteristics found in the mandible and lower dentition. In addition, L. longirostre is somewhat smaller than the latter species (Ziegler \& Mörs 2000). However, on the basis of our limited material, it is not possible to conclude on the assignment of the here studied molars either to the French or to the Austrian species.

Family Dimylidae Schlosser, 1887

\section{Genus Plesiodimylus Gaillard, 1897}

Type species. - Plesiodimylus chantrei Gaillard, 1897.

Diagnosis. - Müller 1967 (English translation in Fejfar \& Sabol 2009, p. 2).

Other species included in Plesiodimylus. - P. huerzeleri Müller, 1967, P. crassidens Engesser, 1980, P. bavaricus Schötz, 1985, P. helveticus Bolliger, 1992, P. johanni Kälin \& Engesser, 2001, P. gaillardi Mein \& Ginsburg, 2002, P. similis Fejfar \& Sabol, 2009.

Remarks. - The validity of some Plesiodimylus species is still questioned. The current classification of the genus suggests the presence of one variable species ( $P$. chantrei), with a large number of more or less local species. It is outside the scope of this paper to add a chapter to the debate, and thus we refer to the extensive discussion presented by Fejfar \& Sabol (2009).

\section{Plesiodimylus sp.}

Figure 2F

2002 Plesiodymilus chantrei Gaillard, 1899. - Hír \& Mészáros, p. 11, fig. 3/5.

Material and measurement. - 1 M1 (PM 2004.375): (L × ant.W-post.W) $2.85 \times 1.87-2.10$. 


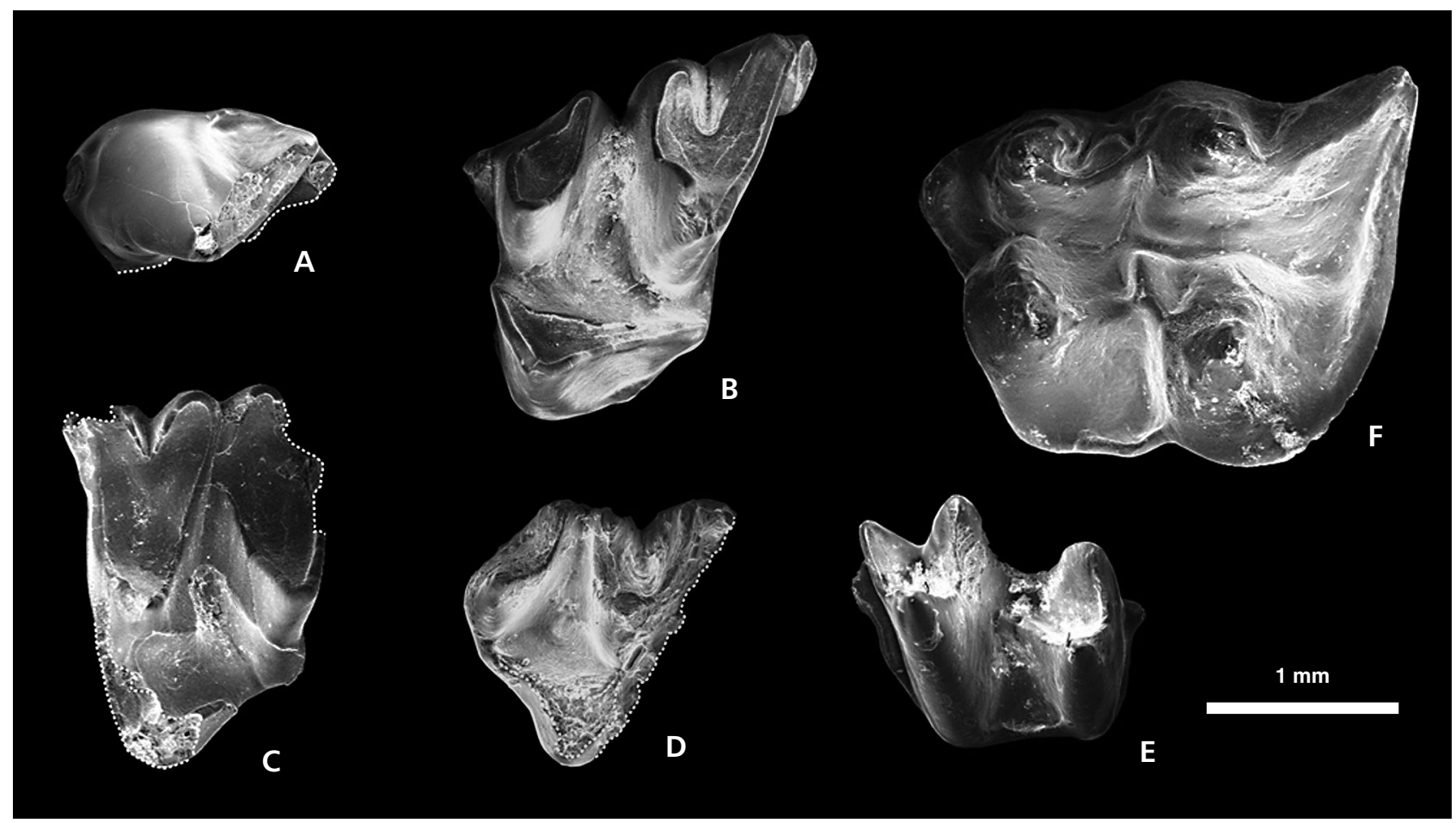

Figure 2. A-E - Desmanodon sp. • A - left P4 (PM 2004.393.5); B - left M1 (PM 2004.380); C - right M2 (reversed, PM 2004.379); D - right M3 (reversed, PM 2004.378); E - right m3 (reversed, PM 2004.376). • F - Plesiodimylus sp., left M1 (PM 2004.375).

Discussion. - Hír \& Mészáros (2002) describe the single Plesiodimylus M1 from S3, and remark that the size of the specimen belongs to the lower part of the variation of $P$. chantrei from Sansan, recently assigned to $P$. aff. chantrei by Engesser (2009), based on differences in size and in the frequency of the presence of the mesostyle in the M1 compared to the type sample of La Grive. Actually, the Hungarian M1 is slightly smaller than the molar samples assigned to P. chantrei (see Fejfar \& Sabol 2009 for size comparison). In addition, the labial wall of the protocone shows a crest-like structure which is not usual in $P$. chantrei (comparison with the figures in Schötz 1985, Engesser 2009). On the other hand, Ziegler (2005) reports two Plesiodimylus species from various fissures filling from the late Middle Miocene from southern Germany. Despite clear differences in size, he assigned most of the fossil material to the species $P$. chantrei. The sample from Petersbuch 31 fits in size and morphology with S3, whereas the remains from Petersbuch 35 are clearly larger.

Although measurements are not provided for Petersbuch 48, the figured specimen (Ziegler 2005, fig. 5G) does not differ from the here studied M1. A single $\mathrm{m} 2$ from the latter locality described by Prieto (2007) is clearly smaller than Petersbuch 35. The assignment of the M1 from S3 to the species from, at least, Petersbuch 31 is justified, but we refrain to definitively accept Ziegler's taxonomic conclusion (P. chantrei). A similar situation as in the German fis- sures was found in Devínska Nová Ves Fissures, from which Fejfar \& Sabol described two different forms. Apart from $P$. chantrei, they found a larger and more amblyodont species, which they name $P$. similis. The S3 specimen is only somewhat smaller than the smallest chantrei M1 from that site.

The recently described $P$. gaillardi from La Grive $\mathrm{M}$ is the smallest species of the genus (Mein \& Ginsburg 2002). The three M1 excavated in the French locality are all smaller than the tooth from S3, but do not differ basically in their morphology (Mein \& Ginsburg 2002, fig. 30). Rzebik-Kowalska (1996) reports small molars from Bełchatóv C (Poland, MN 4), and determines them as P. cf. chantrei. She notices that, apart from the size difference with $P$. chantrei from divers European localities, her sample differs also in minor morphological details as the presence of a well-developed parastyle and a wider metastyle. The here studied M1 differs from this form by the well-developed lingual cingulum, and - with regards to the figured M1 from Bełchatów - the proto- and hypocone having almost the same size.

The high variability of the tooth morphology in Plesiodimylus, and the suspected morphological sexual differences in dimylids (Van den Hoek Ostende 1995), make the comparison difficult. Although an assignment to $P$. chantrei as at present understood (very variable species) is justified, we prefer to leave the species from S3 in open nomenclature. 
Order Soricomorpha Gregory, 1910

Family Soricidae Fischer, 1814

Soricidae incertae sedis

\section{cf. Paenelimnoecus sp.}

Figure $3 \mathrm{~A}-\mathrm{E}$

?pars 1998 Paenelimnoecus crouzeli Baudelot, 1972. - Hír et al., p. 183.

pars 2002 Paenelimnoecus crouzeli Baudelot, 1972. - Hír \& Mészáros, pp. 11, 12, fig. 3, 6a-c.

Material. - 1 right fragmentary mandible with m1-m3 (PM 2004.367); 1 right fragmentary mandible with m1-m2 (PM 2004.368), 3 upper incisors (2 right, 1 left, assignment tentative, PM 2004.370-372); 1 left M1 (PM 2004.373).

Measurements. $-\mathrm{I}(\mathrm{L} \times \mathrm{LT}): 1.67 \times 0.85 ; \mathrm{M} 1(\mathrm{BL} \times \mathrm{PE} \times$ AW): $1.23 \times 1.07 \times 1.43 ; \mathrm{m} 1(\mathrm{~L} \times \mathrm{TRW}-\mathrm{TAW}): 1.40 \times$ 0.80-0.82; m2 (L $\times$ TRW-TAW $): 1.35 \times 0.83-0.77 ; \mathrm{m} 3$ $(\mathrm{L} \times \mathrm{W}): 0.95 \times 0.76$.

Description and discussion. - For descriptions of the specimens PM 2004.367 and 2004.368 we refer to Hír \& Mészáros (2002, p. 12). Three upper incisors are tentatively attributed to this species. They are only slightly larger than the single incisor assigned to Soricidae gen. et sp. indet. The foramen mentale is situated below the middle of the $\mathrm{m} 1$ in the jaw PM 2004.368, somewhat posteriorly in the jaw PM 2004.367, under the posterior root of the $\mathrm{m} 1$. The original attribution to Paenelimnoecus crouzeli is erroneous, because the size of the dental remains is clearly larger than any Paenelimnoecus species, including the large specimens of $P$. repenningi from Austria (Ziegler 2006). Similarly, Gál et al. (1999) report $P$. crouzeli in Mátraszólôs, but the specimens are clearly too large to belong to this species.

The most interesting morphologic characteristic in S3 is the almost complete absence of the entoconid on the $\mathrm{m} 1$ and $\mathrm{m} 2$, a particularity shared with Paenelimnoecus. However, the specimens from S3 also show a strong resemblance to a single unpublished mandible found in the German locality Giggenhausen, which might belong to a new species/genus, but which is provisionally assigned to $\mathrm{cf}$. Hemisorex robustus (Prieto 2007). The only differences between the Hungarian and German molars are the slightly better developed entoconid in Giggenhausen, and the position of the foramen mentale. Compared with the original material of H. robustus from Sansan (Engesser 2009), the teeth from S3 are slightly smaller, with less rectangular outline and reduced entoconid, differences that are sufficient not to assign the material to the French species. Unfortunately, the condyle and the p4 are unknown in S3, thus there are uncertainties concerning the assignment of the specimens, even at the subfamily level. Should it turn out to be a true Paenelimnoecus, it could be assigned to the Allosoricinae (Van den Hoek Ostende et al. 2009a), as a close relative to Hemisorex it would represent a Soricinae. Considering to the lack of important taxonomic characters, it is preferable to be careful concerning the taxonomical assignment of the Hungarian species until new discoveries shed light on this enigmatic taxon.

\section{Soricidae gen. et sp. indet.}

Figure $3 F, G$

?pars 1998 Talpa minuta (Blainville, 1838). - Hír et al., p. 183.

pars 2002 Paenelimnoecus crouzeli Baudelot, 1972. - Hír \& Mészáros, pp. 11, 12.

pars 2002 Talpidae gen. et sp. indet. - Hír \& Mészáros, p. 12.

Material. - 1 fragmentary left mandible with m1-m2 (PM 2004.346); 1 right $\mathrm{m} 1$ (PM 2004.369), 1 left I (PM: 2004.393.14); 1 left M1 (PM 2004.389).

Measurements. $-\mathrm{m} 1(\mathrm{~L} \times$ ant.W-postW): $1.63 \times 0.87-0.98$, $1.50 \times 0.83-0.97 ; \mathrm{m} 2(\mathrm{~L} \times$ ant.W-postW $): 1.57 \times 0.88-0.95$.

Description. - Mandible: The narrow madibular bone is broken anteriorly just before the $\mathrm{m} 1$, and posteriorly behind the missing $\mathrm{m} 3$; the foramen mentale is found under the damaged alveole of the $\mathrm{p} 4$.

$\mathrm{m} 1$ : The highest cuspid is the protoconid; a short and low entocristid closes the talonid basin; the hypolophid runs behind the entoconid; the lower part of the oblique cristid extends to the posterior base of the protoconid; a cingulid is present from the anterior part of the teeth to the postero-labial wall of the hypolophid; two roots.

$\mathrm{m} 2$ : The $\mathrm{m} 2$ differs from the $\mathrm{m} 1$ in the following characters: the trigonid is larger with regard to the talonid, the trigonid basin somewhat narrower, the oblique cristid is directed more lingually, and thus the buccal re-entrant valley is deeper in labial view; the ectocingulid is less curved upward under the re-entrant valley.

I: The corroded incisor is tentatively attributed to this species. It is slightly smaller than the other incisors found in the sample, but, indeed, major morphologic difference cannot be observed.

M1: The tooth is postero-lingually damaged, and a small part of the parastyle is also missing; the posterior arm of the metacone is long; the protocone is connected to the base of the paracone by a crest, whereas the metaloph ends free: a remain of a small hypocone is present; a posterior cingulum is developed on the posterior border of the M1; four roots with in addition a central crest-like low "root".

Discussion. - The upper and lower molars are grouped because of their size. The lack of a p4, a mandibular condyle 

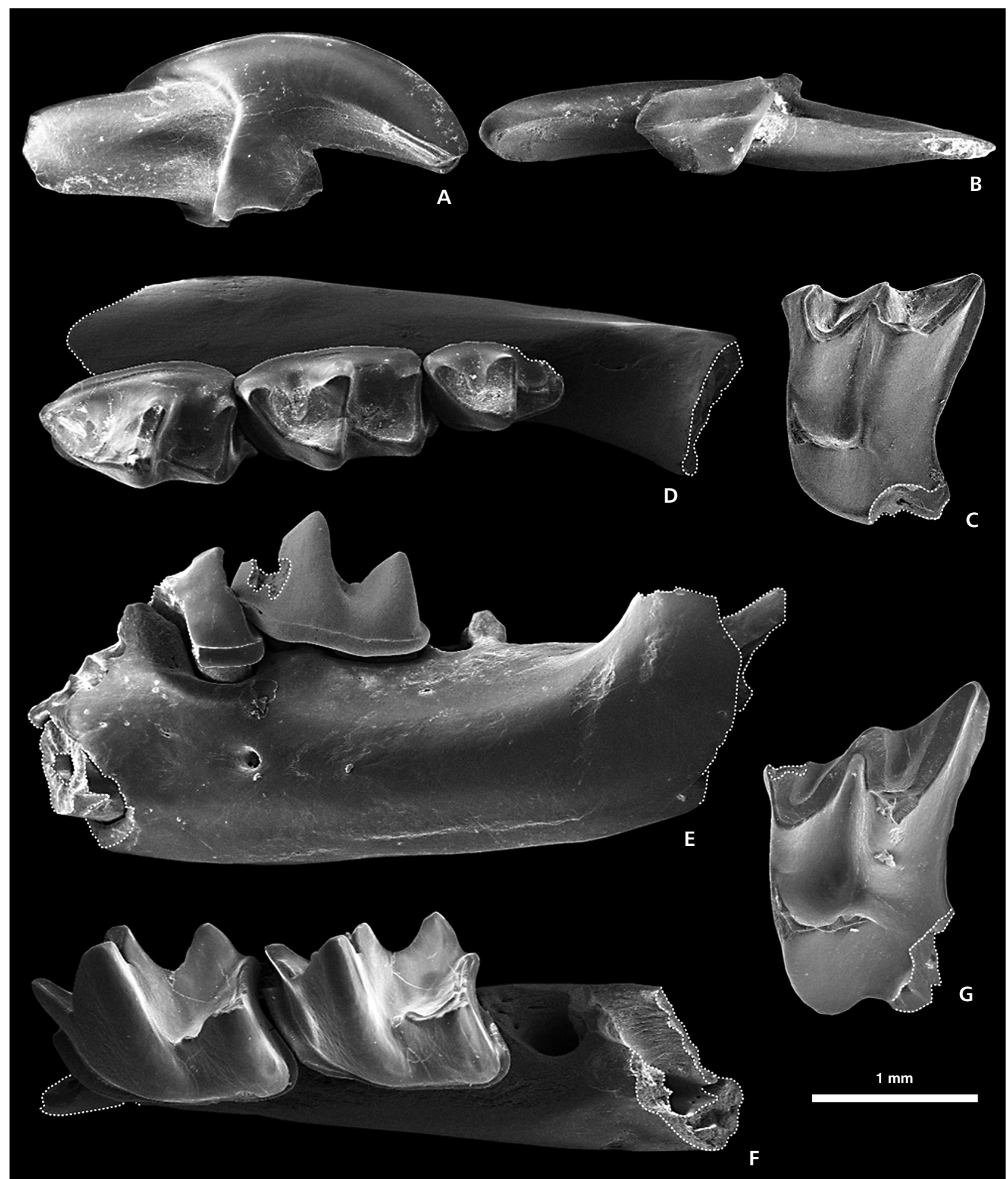

Figure 3. A-E - cf. Paenelimnoecus sp. • A - right I (reversed, assignment uncertain, PM 2004.372, ventral view); B - right I (reversed, assignment uncertain, PM 2004.370, lingual view); C - left M1 (PM 2004.373); D - right mandible with m1-m3 (reversed, PM 2004.367); E - right mandible with m1-m2 (reversed, PM 2004.368, labial view). • F, G - Soricidae gen. et sp. indet. F - left mandible with m1-m2 (PM 2004.346); G - left M1 (assignment uncertain, PM 2004.389). 
and a mandible showing the anterior dentition make the subfamily assignment of the remains difficult. Furthermore the teeth are not particularly specialised. The shrew from S3 shares some similarities with Miosorex grivensis (Depéret, 1892) (see e.g. Ziegler 2003c, fig. 2), but it is also morphologically close to Lartetium prevostianum (Lartet, 1851), especially in the different direction of the oblique cristid in $\mathrm{m} 1$ and $\mathrm{m} 2$. Indeed the molars from $\mathrm{S} 3$ are clearly larger than these two species (see measurements in Engesser 2009). Mein \& Ginsburg (2002) defined L. ziegleri from the late Middle Miocene of La Grive L3 (France). The $\mathrm{m} 1$ and $\mathrm{m} 2$ from $\mathrm{S} 3$ are only slightly larger than the corresponding teeth of this species.

Because of the lack of sufficient material, the genus and species cannot be deduced with certitude from this sample.

Additionally, we note that some shrew fossil material cannot be determinable because of fragmentary condition (PM 2004.377, 2004.393.13, 2004.393.16).

Family Talpidae Fischer, 1814

Subfamily Talpidae incertae sedis

\section{Genus Desmanodon Engesser, 1980}

Type species. - Desmanodon major Engesser, 1980.

Diagnosis. - Engesser (1980, p. 116), differential diagnosis in Engesser (1980, pp. 116, 117).

Other species included. - D. minor Engesser, 1980, D. antiquus Ziegler, 1985 (=D. meuleni Doukas, 1986 in Doukas \& Van den Hoek Ostende, 2006), D. daamsi van den Hoek Ostende, 1997, D. ziegleri Van den Hoek Ostende, 1997, D. burkarti Van den Hoek Ostende, 1997, D. crocheti Prieto, 2010, D. fluegeli Prieto, Gross, Böhmer \& Böhme, 2010.

\section{Desmanodon sp.}

Figure 2A-E

1998 Talpa minuta (Blainville, 1838) - Hír et al., p. 183 pars 2002 Talpidae gen. et sp. indet. - Hír \& Mészáros, p. 12.

Material. - 1 left P4 (PM 2004.393.15); 1 left M1 (PM 2004.380), 1 right M2 (PM 2004.379), 1 left M2 (PM 2004.390), 1 right M3 (PM 2004.378), 1 right m3 (PM 2004.376).

Measurements. - M1: $2.05 \times 1.98 ; \mathrm{m} 3$ (Lxant.W-post.W): $1.58 \times 1.53-1.08$

Description. - P4: The protocone is broken, but the remainder of a relatively strong postcingulum is present, ending in a metastyle; the small ectocingulum is developed on the labial wall of the metacrista; similarly the precingulum is present but does not reach the lingual part of the premolar (style-like structure).

M1: The labial border of the molar is strongly oblique; the mesostyle is strongly divided leading to the formation of a small groove on the labial border of the teeth; the postparacrista and the premetacrista converge; the metaconule and paraconule are missing, although a very small and superficial metaconule may have been present in early stages of wear; the postcingulum is reduced to a small cingulum on the postero-lingual wall of the crown; the narrow metacingulum is interrupted somewhat below the metacone; the metastyle extends posteriorly in a semi-circular structure, that is isolated from the anterior arm of the metacone in occlusal view; the parastyle is a triangular structure, positioned at the base of the antero-labial border of the M1; the paracingulum is reduced to a very small crest at the base of the crown, anteriorly to the protocone; the ectocingulum is missing; three roots.

M2: One molar attributable to a senile Desmanodon is extremely worn, and almost all valuable morphological structure have disappeared. The M2 differs from the M1 in its labial border, which is rather straight, and the paracrista is developed; the posterolingual border is concave; despite the extreme wear, the mesostyle is still divided; there is no evidence of anterior nor posterior cingulum; three strong roots.

M3: The tooth is only slightly worn; the anterior part of the tooth is damaged; the labial border of the molar is directed posterolingually; the metacrista is missing; the mesostyle is clearly divided (not as much as in M1 or M2, see Fig. 2D); there is no ectocingulum; the metaconule is absent; three roots.

$\mathrm{m} 3$ : The $\mathrm{m} 3$ is not worn; the talonid is narrower than the trigonid; the paraconid is somewhat labially positioned in regard to the other two lingual conids; the precingulid is limited in its development to the anterior wall of the paraconid; the oblique cristid descends from the hypoconid to the base of the posterior wall of the protocristid; it runs anteriorly somewhat parallel to the lingual border of the $\mathrm{m} 3$; the entocristid is almost absent, leaving the talonid basin open; the ectocingulid closes the hypoflexid; the entostylid is small and the narrow postcingulid does not extends out of the posterior part of the tooth; the postcristid is transversal.

Discussion. - The strong division of the mesostyle of the upper molars and the low oblique cristid of the lower molar are arguments to assign the talpid remains to the genus Desmanodon. The species from S3 is relatively small (for comparison see the measurements in Prieto 2010, table 2, and Prieto et al. 2010). The lack of sufficient material and taxonomically important information (e.g., premolars), 
does not permit a confident discussion on the specific assignment of the Hungarian form either to D. antiquusrelated forms, $D$. fluegeli from Austria, or D. minor from Turkey. Morphologically, it differs from Desmanodon crocheti from Germany in the lesser division of the mesostyle. The study of other Badenian and Sarmatian insectivore assemblages from Hungary is in progress and might provide supplementary information on the Desmanodon taxonomy, as Hír \& Mészáros (2002, p. 12) found a similar talpid in Hasznos.

Apart from the material described above, S3 also yielded undeterminable dental elements, such as isolated and damaged talonids or trigonids of talpid lower molars and premolars (PM 381-388, 2004.392).

\section{Discussion}

\section{Palaeoenvironmental notes}

With regards to the limited amount of specimens, the insectivore fauna from S3 is relatively diverse with two erinaceids, Parasorex sp. being the dominant species of the sample, and Lantanotherium sp. One dimylid, Plesiodimylus sp., two shrews, cf. Paenelimnoecus sp. and Soricidae gen. et sp. indet., and one mole Desmanodon sp. complete the fauna. Most of the genera are recorded for the first time in Hungary (Parasorex, Lantanotherium, Desmanodon).

The high diversity even in a small sample indicates that conditions were favourable to insectivores, which points to relatively humid conditions. Indeed, dimylids and the erinaceid Lantanotherium are considered to rate among the insectivores most indicative for wet conditions (Furió et al. 2011). On the other hand, the assemblage is dominated by more ubiquitous genera, viz. Parasorex and Desmanodon. Desmanodon is the only talpid to survive in the inlands of Spain during the early Middle Miocene, and is therefore considered not to indicate very humid conditions (Van den Hoek Ostende 1997), and maybe avoiding lake environments (Van den Hoek Ostende \& Fejfar 2006, Prieto 2010). The genus could have been adapted to vegetated alluvial plain with a moist soil cover, similar to the condition found in the Austria locality Gratkorn (Sarmatian sensu stricto, Gross et al. 2007, 2011; Harzhauser et al. 2008; Prieto et al. 2010). The only dimylid in the sample belongs to the most wide spread genus of the family, indicating that Plesiodimylus had a higher ecological tolerance than the other, more water-dependant members. Thus the insectivore points to a humid, though not overly wet environment. Hír \& Mészáros (2002) presume that the vertebrate fauna from S3 was deposited in a lagoon because of the co-occurrence in the site of marine, brackish, freshwater and continental molluscs. Furthermore, the presence of thermophilic ectotherm crocodiles (Hír \& Mészáros 2002) indicates that the Middle Miocene Climatic Optimum is not finished at the time of the deposition of the S3 fauna.

\section{Biostratigraphical notes}

The Central and East European Middle Miocene insectivore record is poorly documented from a biostratigraphic point of view (Van den Hoek Ostende et al. 2005, 2009b), and it is especially true for Hungary. Indeed, based on the present knowledge, it is not possible to clearly understand the effects of bio-provinciality, the faunal interchanges and to document precisely the lineages. The insectivore sample from Sámsonháza is more primitive than any Sarmatian samples. For instance, among the Erinaceidae Schizogalerix voesendorfensis is recorded at the beginning of the late Sarmatian of Austria (Prieto et al. 2010) and the preliminary study of the material from the Felsôtárkány sections (see e.g. Hír \& Kókay 2010) for information and references on the localities) confirms that also a clear Schizogalerix form is present in the late Sarmatian of Hungary. Parasorex socialis, which shares morphological characteristics with the material from S3, is an immigrant in the North Alpine Foreland basin (NAFB), where it is an abundant element of the faunas during the MN 7 and 8 (sensu Kälin et al. 2001, Kälin \& Kempf 2009). Its origin cannot be found west from the NAFB as supported by the rich Iberian fossil record (Prieto et al. 2011), thus an eastern origin of the species has to be assumed. The first occurrence of Parasorex socialis in South Germany is correlated to the MN 6 (Prieto \& Rummel 2009a), based on the occurrence of the cricetid rodent Megacricetodon aff. germanicus in the German locality Petersbuch 68 (upper part of the fissure filling, Prieto \& Rummel 2009b). This species probably corresponds to the Swiss $M$. gersii samples studied by Kälin \& Kempf (2009). The authors correlate the first occurrence (FO) of the species from Sansan in Switzerland at the base of their Democricetodon gracilis-M. gersii interval zone, at around 14.6 My (although that, in their figure 8, M. gersii seems to appear somewhat later at around 14.2 My). Megacricetodon is reported in $\mathrm{S} 3$ only by a smaller species, assigned to M. minor by Hír \& Mészáros (2002). Indeed, clear morphological differences appear between the two species, like, for example, the development of an anteromesolophid in the $\mathrm{m} 1$ of the Hungarian sample, an infrequent structure in Sansan, the type locality of the species (Maridet \& Sen in press, J. Prieto pers. opinion). It fits well with $M$. aff. similis from diverse fissure fillings from Petersbuch (MN 6-8, Prieto 2007, Prieto \& Rummel 2009b), assigned to M. similis in the Swiss Molasse (Kälin \& Kempf 2009, FO: around 14.2 My). It also shares characteristics with $M$. andrewsi from Pașalar (Peláez-Campomanes \& Daams 2002), and is probably also related to $M$. collongensis from Çandir (De Bruijn et al. 2003). 
Based on these considerations, the fauna from S3 consists of forms entering the Central European basins around the end of the Badenian. This is in agreement with the Middle Badenian correlation proposed by Hír \& Mészáros (2002) based on the rich molluscan fauna of the locality, near to the end of the Middle Miocene Climatic Optimum.

\section{Conclusions}

The study of the insectivores from Sámsonháza 3 reveals a taxonomically rich community, and indicates a relatively wet environment at the Middle Badenian. The importance of the Hungarian small mammals in the comprehension of the evolution and migration of the faunas during the European Middle Miocene is thus confirmed. Evidently, this sample alone is insufficient to make any substantial comments regarding the biogeography. As a result, the rich and still unstudied Hungarian insectivore material, ranging from the early Badenian to the boundary Middle/Late Miocene (Hír 2010), is of primary importance in the comprehension of the European faunal evolution, in a large scaled context.

\section{Acknowledgments}

The authors express their sincere thank to Lukács G. Mészáros (Szentendre). Ursula Göhlich (Naturhistorisches Museum Wien) gave us access to the material from Grund and Mühlbach, which was very helpful in shaping our ideas. This study was supported by the Deutsche Forschungsgemeinschaft grant BO1550/16-1, the project No. T046719 of the Hungarian Scientific Research Fund (OTKA), and the SYNTHESYS Project (NL-TAF-619) http://www.synthesys.info/ which is financed by European Community Research Infrastructure Action under the FP7 "Capacities" Program.

\section{References}

BAUdELot, S. 1972. Etude des Chiroptères, Insectivores et Rongeurs du Miocène de Sansan (Gers). 364 pp. Ph.D. thesis, Université Paul Sabatier, Toulouse, France.

Bolliger, T. 1999. Family Anomalomyidae, 411-420. In RössNER, G. \& HeIssig, K. (eds) The miocene land mammals of Europe. Pfeil, München.

BöHme, M. 2003. Miocene Climatic Optimum: evidence from Lower Vertebrates of Central Europe. Palaeogeography, Palaeoclimatology, Palaeoecology 195(3-4), 389-401. DOI 10.1016/S0031-0182(03)00367-5

Bruijn, H. DE, Fahlbusch, V., Saraç, G. \& Ünay, E. 1993. Early Miocene rodent faunas from the eastern mediterranean area Part III. The genera Deperetomys and Cricetodon with a discussion of the evolutionary history of the Cricetodontini. Proceedings of the Koninklijke Nederlandse Akademie van Wetenschappen 96(2), 151-216.
Bruijn, H. de, Hoek Ostende, L.W. van den, Kristkoiz-Boon, E., Rummel, M., Therocharopoulos, C. \& Ünay, E. 2003. Rodents, lagomorphs and insectivores, from the middle Miocene hominoid locality of Çandir (Turkey). Courier Forschungsinstitut Senckenberg 240, 51-87.

ButLER, P.M. 1980. The giant erinaceid insectivore, Deinogalerix Freudenthal, from the upper Miocene of Gargano, Italy. Scripta geologica 57, 1-72.

DoukAS, C.S. 1986. The mammals from the Lower Miocene of Aliveri (Island of Evia, Greece). Proceedings of the Koninklijke Nederlandse Akademie van Wetenschappen B 89, $15-38$.

Doukas, C.S. \& Hoek Ostende, L. van den 2006. Insectivores (Erinaceomorpha, Soricomorpha; Mammalia) from Karydia and Komotini (Thrace, Greece; MN 4/5). Beiträge zur Paläontologie 30, 109-131.

ENGESSER, B. 1972. Die obermiozäne Säugertierefauna von Anwil (Baselland). Tätigkeitsberichte der Naturforschenden Gesellschaft Baselland 28, 37-363.

ENGESSER, B. 1980. Insectivora and Chiroptera (Mammalia) aus dem Neogen der Türkei. Schweizerische Paläontologische Abhandlungen 102, 45-149.

ENGESSER, B. 2009. The Insectivores (Mammalia) from Sansan (Middle Miocene, south-western France). Schweizerische Paläontologische Abhandlungen 128, 1-91.

Fejfar, O. \& Sabol, M. 2009. Middle Miocene Plesiodimylus from the Devínska Nová Ves-Fissures site (western Slovakia). Bullletin of Geosciences 84(4), 611-624.

DOI 10.3140/bull.geosci. 1148

Furió, M., Casanovas-Vilar, I. \& Hoek Ostende, L.W. van den 2011. Predictable structure of Miocene insectivore (Lipothyphla) faunas in western Europe along a longitudinal gradient. Palaeogeography, Palaeoclimatology, Palaeoecology 304, 219-229. DOI 10.1016/j.palaeo.2010.01.039

Furió, M., Casanovas-Vilar, I., Moyà-Solà, S., Köhler, M., Galindo, J. \& AlBA, D. 2011. Insectivores (Eulipotyphla; Mammalia) from the Middle Miocene of Barranc de Can Vila 1 (Vallès-Penedès Basin, Catalonia, Spain). Geobios 44, 199-213. DOI 10.1016/j.geobios.2010.10.002

Gál, E., Hír, J., Kessler, E., Kókay, J., Mészáros, L. \& VenCZEL, M. 1999. Középsô-miocén ôsmaradványok a Mátraszőlős, Rákóczi-kápolna alatti útbevágásból.1. A Mátraszőlős 1. lelőhely [Middle Miocene fossils from the road cut at Mátraszôlós, Rákóczi-kápolna. I. The Mátraszőloos $1^{\text {st }}$ locality]. Folia historico-naturalia Musei Matraensis 23, 33-78.

Gál, E., Hír, J., Kessler, E., Kókay, J. \& Venczel, M. 2000. Középsô-miocén ősmaradványok a Mátraszőlős, Rákóczikápolna alatti útbevágásból II. A Mátraszólós 2. lelőhely [Middle Miocene fossils from the road cut at Mátraszólôs, Rákóczi-kápolna II. The Mátraszólős $2^{\text {nd }}$ locality]. Folia historico-naturalia Musei Matraensis 24, 39-75.

Ginsburg, L. \& Bulot, C. 2000. Le cadre stratigraphique du site de Sansan. Bulletin du Museum National d'Histoire naturelle Paris 83, 39-67.

Gross, M., Fritz, I., Piller, W.E., Soliman, A., Harzhauser, M., Hubmann, B., Moser, B., Schloger, R. \& Suttner, T.J. 2007. The Neogene of the Styrian Basin - Guide to excursion. Joannea - Geologie und Paläontologie 9, 117-193. 
Gross, M., Böhme, M. \& Prieto, J. 2011. Gratkorn: A benchmark locality for the continental Sarmatian s. str. of the Central Paratethys. International Journal of Earth Sciences (Geologische Rundschau) 100, 1895-1913. DOI 10.1007/s00531-010-0615-1

Hámor, G. 1985. Geology of the Nógrád-Cserhát area. Geologica Hungarica 22, 1-307.

Harzhauser, M., Gross, M. \& Binder, H. 2008. Biostratigraphy of Middle Miocene (Samartian) wetland systems in an Eastern Alpine intramontane basin (Gratkorn Basin, Austria): the terrestrial gastropod approach. Geologica Carpathica 59(1), $45-58$.

HAAs, J. 2001. Geology of Hungary. 317 pp. Eőtvős University Press, Budapest.

Hír, J. 2010. A short sketch on the studies of middle Miocene fossil rodent faunas in the Pannonian Basin. Zitteliana B 29, 50.

Hír, J., KókAy, J., Mészáros, L. \& Venczel, M. 1998. Középsö miocén puhatestü és gerinces maradványok a sámsonházi Oszkoruzsa-árokból. [Miocene molluscan and vertebrates remains from the Oszkoruzsa Valley at Sámsonháza]. Nógrád Megyei Múzeumok Évkönyve 22, 171-204.

Hír, J. \& MÉszÁros, L.G. 2002. Middle Miocene insectivores and rodents (Mammalia) from Sámsonháza (Northern Hungary). Fragmenta Palaeontologica Hungarica 20, 9-23.

Hír, J. \& KóKay, J. 2004. Middle Miocene molluscs and rodents from Mátrazőloos (Mátra Mountains, Hungary). Fragmenta Palaeontologica Hungarica 22, 83-97.

Hír, J. \& KóKAY, J. 2010. A systematic study of the middle-late Miocene rodents and lagomorphs (Mammalia) of Felsôtárkány 3/8 and 3/10 (Northern Hungary) with stratigraphical relations. Geodiversitas 32, 307-329.

Hoek Ostende, L.W. van DEN 1992. Insectivores faunas from the Lower Miocene of Anatolia. Part 1: Erinaceidae. Proceedings of the Koninklijke Nederlandse Akademie van Wetenschappen 95(4), 437-467.

Hoek Ostende, L.W. van DEN 1995. Insectivore faunas from the Lower Miocene of Anatolia. Part 3: Dimylidae. Proceedings of the Koninklijke Nederlandse Akademie van Wetenschappen 98(1), 19-38.

Hoek Ostende, L.W. van den 1997. Insectivore faunas from the Lower Miocene of Anatolia. Part 4: The genus Desmanodon (Talpidae) with the description of a new species from the Lower Miocene of Spain. Proceedings of the Koninklijke Nederlandse Akademie van Wetenschappen 100(1-2), $27-65$.

Hoek Ostende, L.W. van den 2001a. A revised generic classification of the Galericini (Insectivora, Mammalia) with somes remarks on their palaeogeography and phylogeny. Geobios 34(6), 681-695. DOI 10.1016/S0016-6995(01)80029-2

Hoek Ostende, L.W. van DEN 2001b. Insectivore faunas from the Lower Miocene of Anatolia - Part 7: The Kargi assemblages. Scripta Geologica 122, 83-99.

Hoek Ostende, L.W. van den \& Doukas, C.S. 2003. Distribution and evolutionairy history of the Early Miocene erinaceid $\mathrm{Ga}$ lerix symeonidisi Doukas, 1986, 287-303. In Reumer, J.W.F. \& Wessels, W. (eds) Distribution and migration of Tertiary mammals in Eurasia. A volume in honour of Hans de Bruijn. Deinsea 10.

Hoek Ostende, L.W. van den, Doukas, C.S. \& Reumer, J.W.F. (eds) 2005. The fossil record of the Eurasian Neogene insectivores (Erinaceomorpha, Soricomorpha, Mammalia): Part I. Scripta Geologica, Special Issue 5, 1-300.

Hoek Ostende, L.W. van den \& Fejfar, O. 2006. Erinaceidae and Talpidae (Erinaceomorpha, Soricomorpha, Mammalia) from the Lower Miocene of Merkur-Nord (Czech Republic, MN 3). Beiträge zur Paläontologie 30, 175-203.

Hoek Ostende, L.W. van den, Furió, M. \& Garcá-Paredes, I. 2009a. New data on Paenelimnoecus from the middle Miocene of Spain support the shrew subfamily Allosoricinae. Acta Palaeontologica Polonica 54(1), 159-164.

DOI 10.4202/app.2009.0117

Hoek Ostende, L.W. van den, Reumer, J.W.F. \& Doukas, C.S. 2009b. The nature of the fossil record of Neogene insectivores. Hellenic Journal of Geosciences 44, 117-124.

Kälin, D. \& Engesser, B. 2001. Die jungmiozäne Säugertierfauna vom Nebelbergweg bei Nunningen (Kanton Solothurn, Schweiz). Schweizerische Paläontologische Abhandlungen 121, 1-61.

Kälin, D., Weidmann, M., Engesser, B. \& Berger, J.-P. 2001. Paléontologie et âge de la Molasse d'eau douce supérieure (OSM) du Jura Neuchâtelois. Schweizerische Paläontologische Abhandlungen 121, 63-101.

KäLIN, D. \& KeMPF, O. 2009. High-resolution stratigraphy from the continental record of the Middle Miocene northern Alpine Foreland Basin of Switzerland. Neues Jahrbuch für Geologie und Palaeontologie, Abhandlungen 254(1-2), 177-235.

KoRDiKova, E.G. 2000. Insectivora (Mammalia) from the Lower Miocene of the Aktau Mountains, South-Eastern Kazakhstan. Senckenbergiana lethaea 80(1), 67-79.

KoRDOs, L. 1986. A hasznosi felsô-miocén gerinces lelöhely kora emlőszonáció alapján. [Upper Miocene hamsters (Cricetidae, Mammalia) of Hasznos and Szentendre: a taxonomic and stratigraphic study.]. Magyar Állami Földtani Intézet Évi Jelentése 1984, 523-553.

Maridet, O. \& Sen, S. (in press). Les Cricetidae du gisement de Sansan. In Peigne, S. \& Sen, S. (eds) Les mammifères du gisement de Sansan. Mémoire du Muséum d'Histoire Naturelle de Paris, numéro spécial.

Mein, P. \& Ginsburg, L. 2002. Sur l'âge relatif des différents dépôts karstiques miocènes de la Grive-Saint-Alban (Isère). Cahiers scientifiques Muséum d'Histoire naturelle Lyon 2, $7-47$.

MÉszÁros, L.G. 2000a. New results for the Late Miocene Soricidae stratigraphy of the Pannonian basin. Newsletters on Stratigraphy 38(1), 1-11.

MÉszÁros, L.G. 2000b. Paleogeography and environment of the late Miocene Soricidae (Mammalia) fauna of the Pannonian Basin. Annales Universitatis Scientarium Budapestiensis, Sectio Geologica 33, 107-120.

Müller, A. 1967. Die Geschichte der Familie Dimylidae (Insectivora, Mamm.) auf Grund der Funde aus tertiären Spaltenfüllungen Süddeutschlands. Abhandlungen der Bayerischen Akademie der Wissenschaften, mathematisch-naturwissenschaftliche Klass (Neue Folge) 129, 1-93.

Munthe, J. \& West, R.M. 1980. Insectivora of the Miocene Daud Khel Local Fauna, Mianwali District, Pakistan. Contributions in Biology and Geology 38, 1-17.

Peláez-Campomanes, P. \& Daams, R. 2002. Middle Miocene ro- 
dents from Pașalar, Anatolia, Turkey. Acta Palaeontologica Polonica 47(1), 125-132.

PRIETO, J. 2007. Kleinsäuger-Biostratigraphie und Paläoökologie des höheren Mittelmiozäns (MN 8) Bayerns: Spaltenfüllungen der Fränkischen Alb und Lokalitäten der Oberen Süßwassermolasse im Vergleich. 213 pp. Ph.D. thesis, Ludwig-Maximilian-Universität, Munich, Germany.

Prieto, J. 2010. The Middle Miocene mole Desmanodon crocheti sp. nov. (Talpidae, Mammalia): the last representative of the genus in the North Alpine Foreland Basin. Paläontologische Zeitschrift 84(2), 217-225. DOI 10.1007/s12542-009-0038-0

Prieto, J. \& Rummel, M. 2009a. Erinaceidae (Mammalia, Erinaceomorpha) from the Middle Miocene fissure filling Petersbuch 68 (South Germany). Zitteliana 48-49, 103-111.

Prieto, J. \& Rummel, M. 2009b. Small and medium sized Cricetidae (Mammalia, Rodentia) from the Middle Miocene fissure filling Petersbuch 68 (South Germany). Zitteliana 48-49, 89-102.

Prieto, J., Gross, M., Böhmer, C. \& Böhme, M. 2010. Insectivores and bat (Mammalia) from the late Middle Miocene of Gratkorn (Austria): biostratigraphic and ecologic implications. Neues Jahrbuch für Geologie und Palaeontologie, Abhandlungen 258, 107-119.

DOI 10.1127/0077-7749/2010/0088

Prieto, J., Hoek Ostende, L.W. van den \& Böhme, M. 2011. Reappearance of Galerix (Erinaceomorpha, Mammalia) at the limit Middle/Upper Miocene in South Germany: biostratigraphical and paleoecological implications. Contributions to Zoology 80(3), 179-189.

ReUmer, J.W.F. 1984. Ruscinian to Early Pleistocene Soricidae (Insectivora, Mammalia) from Tegelen and Hungary. Scripta Geologica 73, 1-173.

Rzebik-Kowalska, B. 1996. Insectivora (Mammalia) from the Miocene of Bełchatów, Poland. III. Dimylidae Schlosser, 1887. Acta Zoologica Cracoviensia 39(1), 447-468.

Schöтz, M. 1985. Die Dimyliden (Mammalia, Insectivora) aus der Kiesgrube Maßendorf (Obere Süßwassermolasse Niederbayerns). Mitteilungen der Bayerischen Staatssammlung für Paläontologie und historische Geologie 25, 95-130.

Sen, S. \& Ginsburg, L. 2000. La magnétostratigraphie du site de Sansan. Bulletin du Museum National d'Histoire naturelle Paris 83, 69-81.

Thenius, E. 1949. Zur Revision der Insektivoren des steirischen Tertiärs. Sitzungsberichte der Österrischen Akademie der Wissenschaften, mathematisch-naturwissenschaftliche Klasse, Abteilung 1, 159(9/10), 671-693.

Vasileiadou, K. \& Koufos, G.D. 2005. The micromammals from the Early/Middle Miocene locality of Antonios, Chalkidiki, Greece. Annales de Paléontologie 91, 197-225.

DOI 10.1016/j.annpal.2005.06.002

Venczel, M. 2004. Middle Miocene anurans from the Carpathian Basin. Palaeontographica, Abteilung A 271(5-6), 151-174.

VenCZEL, M. 2008. A new salamandrid amphibian from the Middle Miocene of Hungary and its phylogenetic relationships. Journal of Systematic Palaeontology 6, 41-59.

DOI 10.1017/S1477201907002283

Venczel, M. 2011. Middle-Late Miocene snakes from the Pannonian Basin. Acta Palaeontologica Romaniae 7, 343-349.

Venczel, M. \& Csiki, Z. 2002. Mesozoic and Neozoic anurans (amphibian: Anura) from the Carpathian Basin. $7^{\text {th }}$ European Workshop on Vertebrate Palaeontology, Sibiu (Romania), July 2-7, 2002, 36.

Venczel, M. \& ȘtiuCÃ, E. 2008. Late middle Miocene amphibians and squamate reptiles from Tauț, Romania. Geodiversitas 30(4), 731-763.

ZIEGLER, R. 1989. Heterosoricidae und Soricidae (Insectivora, Mammalia) aus dem Oberoligozän und Untermiozän Süddeutschlands. Stuttgarter Beiträge zur Naturkunde Serie B $154,1-73$.

ZIEGLER, R. 1999. Order Insectivora, 53-74. In RÖSSNER, G. \& HeIssig, K. (eds) The miocene land mammals of Europe. Pfeil, Munich.

ZIEGLER, R. 2003a. Moles from the late Middle Miocene of South Germany. Acta Palaeontologica Polonica 48, 617-648.

ZIEGLER, R. 2003b. Insektenfresser (Lipotyphla) aus dem MittelMiozän von Mühlbach am Manhartsberg und Grund, Niederösterreich. Annalen des Naturhistorischen Museums in Wien 104 A, 251-265.

ZIEGLER, R. 2003c. Shrews (Soricidae, Mammalia) from Middle Miocene karstic fissure fill sites of Petersbuch near Eichstätt, Southern Franconian Alb (Bavaria). Paläontologische Zeitschrift 77, 303-322.

ZIEGLER, R. 2005. Erinaceidae and Dimylidae (Lipotyphla) from the Upper Middle Miocene of South Germany. Senckenbergiana lethaea $85,131-152$.

ZIEGLER, R. 2006. Insectivores (Lipotyphla) and Bats (Chiroptera) from the Late Miocene of Austria. Annalen des Naturhistorischen Museums Wien 107 A, 93-106.

ZIEGLER, R. \& FAHLBUSCH, V. 1986. Kleinsäuger-Faunen aus der basalen Oberen Süßwasser-Molasse Niederbayerns. Zitteliana $14,3-58$.

ZIEGLER, R. \& Mörs, T. 2000. Marsupialia, Lipotyphla und Chiroptera (Mammalia) aus dem Miozän des Braunkohlentagebaus Hambach (Niederrheinische Bucht, NW-Deutschland). Paleontographica A 257, 1-26. 